Рекомендована д. хім. наук, доц. В. С. Матійчуком

УДК 547.789:542.91:615.015.4

DOI 10.11603/2312-0967.2018.3.9316

\title{
ВИВЧЕННЯ БУДОВИ ПРОДУКТУ ВЗАЄМОДІї ДИЛТІАЗЕМУ 3 БРОМКРЕЗОЛОВИМ ЗЕЛЕНИМ
}

\author{
СМ. І. Сулима ${ }^{1}$, В. В. Огурцов ${ }^{1}$, Ю. М. Жук², С. О. Васюк², С. В. Хом'як
}

Львівський національний медичний університет імені Данила Галицького ${ }^{1}$

Запорізький державний медичний університет

Інститут хімії та хімічних технологій Національного університету «Львівська

політехніка»³

Sumarta145@gmail.com

\begin{abstract}
Мета роботи. Виділення та ідентифрікація продукту взаємодії дилтіазему гідрохлориду з бромкрезоловим зеленим. Матеріали і методи. У дослідженні використано робочий стандартний зразок дилтіазему гідрохлориду, бромкрезоловий зелений (БКЗ), зразки готових лікарських фрорм вітчизняного та закордонного виробництва. Реагенти і розчинники: стандартний зразок дилтіазему гідрохлориду, бромкрезоловий зелений, ацетон.

Аналітичне обладнання: спектрофоотометр Bruker Alpha (Bruker Optik GmbH, Ettlingen, Germany) з використанням приставки (повного внутрішнього відбиття) ATR (пряме уведення речовини), спектрофотометр Specord 200 (Німеччина) (190-1100 нм).

Результати й обговорення. Експериментально встановлено, що дилтіазем гідрохлорид взаємодіє 3 бромкрезоловим зеленим у середовищі ацетону з утворенням йонного асоціату. ІЧ-спектр йонного асоціату відповідає сумі поглинань вихідних сполук із деякими відмінностями, що підтверджують його утворення. У йонному асоціаті в області 3600-3400 см-1 смуги фенольних -ОН проявляються 3 меншою інтенсивністю, що можна пояснити перетворенням БКЗ у хінонну структуру. У продукті також відсутні поглинання в області $2370 \mathrm{~cm}^{-1}\left(\mathrm{R}_{3} \mathrm{~N}^{+} \mathrm{Cl}^{-}\right.$ в дилтіаземі гідрохлориді), що пояснюється утворенням йонного асоціату з БКЗ, а саме поглинання проявляється у вигляді уширеного сигналу в області 3200-2000 см-1.

Висновки. У результаті проведених досліджень встановлено, що дилтіазем гідрохлорид взаємодіє 3 бромкрезоловим зеленим у співвідношенні 1:1, виділено та встановлено будову продукту взаємодії дилтіазему гідрохлорид із бромкрезоловим зеленим. За допомогою ІЧ-спектроскопії підтверджено, що продуктом реакції $€$ йонний асоціат.
\end{abstract}

Ключові слова: дилтіазему гідрохлорид; бромкрезоловий зелений; йонний асоціат, спектрофотометрія.

Вступ. Згідно з Державним фрормуляром лікарських засобів за класифікацією АТС, дилтіазем гідрохлорид належить до групи селективних антагоністів кальцію з домінуючим впливом на серце. За даними літератури, для кількісного визначення дилтіазему гідрохлориду головним чином використовують метод високоефрективної рідинної хроматографрії [1-5]. Для аналізу дилтіазему гідрохлориду як у субстанції, так і у фрармацевтичних препаратах, у літературі в достатній кількості представлено спектрофотометричні методики. Так, бразильські вчені описали три прості, точні та чутливі спектрофотометричні методики. Перший спосіб базується на окисненні дилтіазему гідрохлориду $\mathrm{N}$-бромсукцинімідом та визначенні кількості $\mathrm{N}$-бромсукциніміду, що не прореагував у спосіб вимірювання зменшення абсорбції амарантного барвника при довжині хвилі $\lambda_{\max }=521$ нм. Інші методики передбачають додавання надлишку церію сульфрату 3 наступним визначенням кількості окисника шляхом зменшення інтенсивності червоного кольору хромотропу $2 \mathrm{R}(\mathrm{C} 2 \mathrm{R})$ при $\lambda_{\max }=528$ нм або зменшення інтенсивності оранжево-рожевого кольору родаміну 6G при $\lambda_{\max }=525$ нм, відповідно. Підпорядкування закону Бера відбувається в межах концентрацій 3.0 -9.0, 3.5 - 7.0 і 3.5 - 6.3 мкг мл $^{-1}$ для першого, другого та третього методів відповідно [6]. Для визначення мікрокількостей дилтіазему запропоновано спектрофотометричний метод, що ґрунтується на відновленні купруму (II) в буферному розчині $(\mathrm{pH} 7,0)$ та використання міцелярного середовища, що містить 4,4'-дикарбокси-2,2'-біхінолінову кислоту. Відновлений купрум (I) реагує 3 4,4'-дикарбокси-2,2'біхіноліновою кислотою, а світлопоглинання утворених комплексів вимірюють спектрофотометрично при 558 нм [7].

Ми розробили методику кількісного визначення дилтіазему гідрохлориду в субстанції та у складі лікарських фрорм на основі його взаємодії з сульфоор-

ISSN 2312-0967. Фармацевтичний часопис. 2018. № 3 
талеїновим барвником, а саме бромкрезоловим зеленим (БКЗ), у середовищі ацетону [8]. Наступним етапом була ідентифрікація складу сполуки, що утворюється в результаті хімічної взаємодії досліджуваної сполуки з сульфрофталеїновим барвником. Отже, метою роботи було виділення та ідентифікація продукту взаємодії дилтіазему гідрохлориду з бромкрезоловим зеленим. Для реалізації даної мети вирішували такі завдання:

- встановлення стехіометричних коесріцієнтів взаємодії дилтіазему гідрохлориду з бромкрезоловим зеленим;

- виділення продуктів взаємодії дилтіазему гідрохлориду з бромкрезоловим зеленим;

- вивчення будови продукту взаємодії дилтіазему гідрохлориду з бромкрезоловим зеленим.

Матеріали і методи. Об'єкт дослідження - РС3 дилтіазему гідрохлориду (Changzhou Pharmaceutical Factory, KHP).

У роботі використано реактиви і розчинники: бромкрезоловий зелений (кваліфікації чда), ацетон (кваліфрікації чда).

Загальні методи дослідження:

- стехіометричні коесріцієнти реагуючих речовин встановлювали методом насичення (методом молярних співвідношень) та методом неперервних змін (методом ізомолярних серій);

- ІЧ-спектри реєструвались на спектрофротометрі Bruker Alpha (Bruker Optik GmbH, Ettlingen, Germany) в області 4000-400 см-1 з використанням приставки (повного внутрішнього відбиття) ATR (пряме уведення речовини);

- спектри поглинання забарвлених продуктів реакцій у видимій області спектра - на спектрофотометрі Specord 200 (Німеччина) (190-1100 нм). Одержані спектри обробляли із застосуванням програмного пакета WinASPECT 2.2.1.0.

Результати й обговорення. Визначення стехіометричних коефіцієнтів реагуючих компонентів у реакції між дилтіазему гідрохлоридом і бромкрезоловим зеленим

Для встановлення стехіометричних коесріцієнтів реагуючих компонентів у реакції між дилтіазему гідрохлоридом і бромкрезоловим зеленим використовувались найбільш розповсюджені методи: метод неперервних змін (метод ізомолярних серій) та метод насичення (метод молярних співвідношень).

Метод неперервних змін ґрунтується на визначенні відношення ізомолярних концентрацій реагуючих речовин, що відповідає максимальному виходу утвореного продукту. Для виконання аналізу готували розчини реагенту та досліджуваної лікарської речовини однакової молярної концентрації (0,0075 M) та змішували їх у антибатних співвідношеннях (від 1:9 до 9:1), залишаючи загальний об'єм розчину незмінним.

Реакцію проводили згідно з розробленою методикою [8].
Вимірювання абсорбції отриманих розчинів проводили при обраній аналітичній довжині хвилі. За отриманими даними побудовано графік залежності величини оптичної густини від співвідношення об'ємів компонентів ізомолярних серій (рис. 1).

Метод молярних співвідношень $€$ розповсюдженим методом дослідження сполук. Суть методу полягає у встановленні залежності від концентрації одного $з$ компонентів при сталій концентрації іншого і навпаки. Точка зламу на кривій відповідає відношенню стехіометричних коефріцієнтів, що дорівнює еквівалентній концентрації компонентів (рис. 2).

Як видно 3 даних рисунків 1 і 2, стехіометричні співвідношення реагуючих компонентів «дилтіазем БКЗ», одержані методами неперервних змін та методом насичення, повністю погоджуються між собою і становлять співвідношення 1:1.

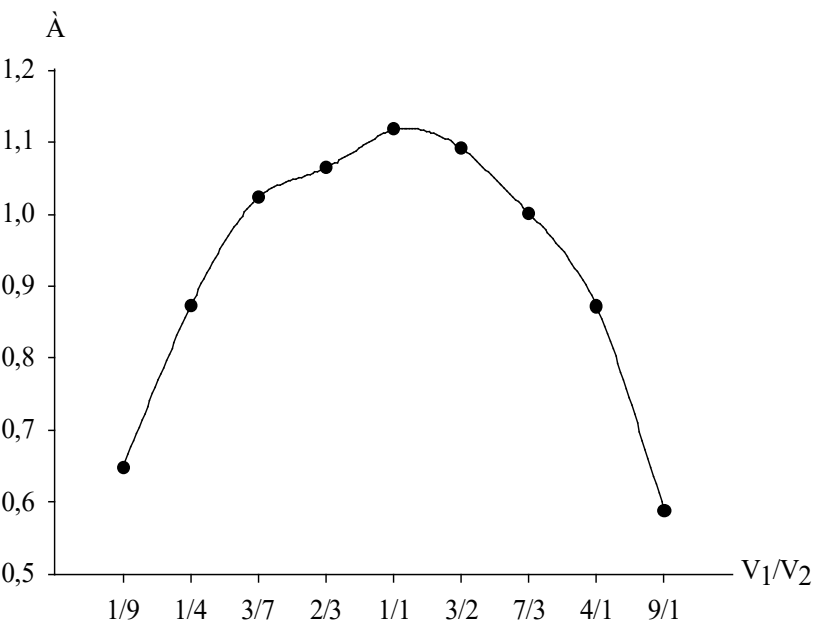

Рис. 1. Грасрік залежності величини оптичної густини від складу ізомолярного розчину $\left(C_{1}-0,0075\right.$ М розчин БКЗ, С - 0,0075 М розчин дилтіазему гідрохлориду).

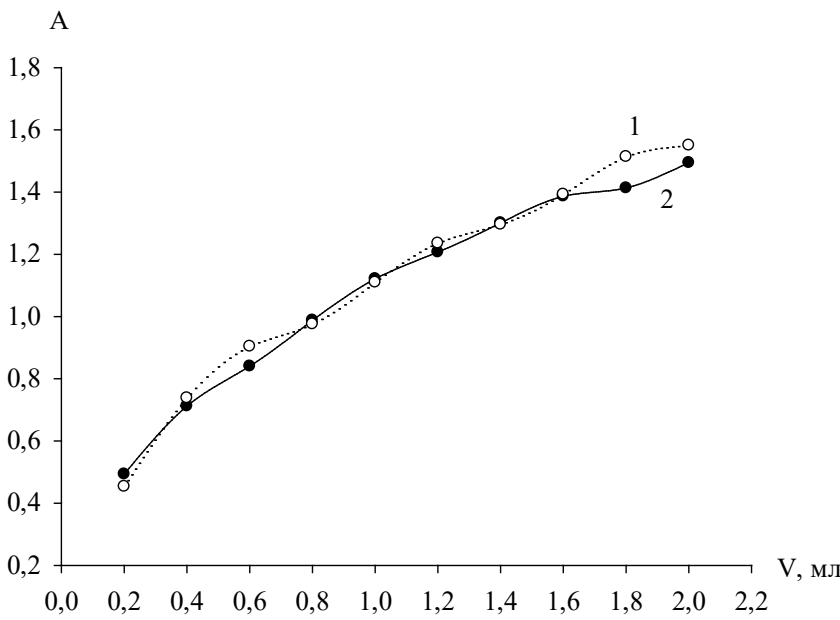

Рис. 2. Криві насичення: 1 - БКЗ при постійній концентрації дилтіазему (1,00 мл 0,0075 М розчину); 2 - дилтіазему при постійній концентрації БК3 (1,00 мл 0,0075 М розчину).

ISSN 2312-0967. Pharmaceutical review. 2018. № 3 


\section{Analysis of drugs}

Виділення продукту взаємодії дилтіазему гідрохлориду з бромкрезоловим зеленим

Відповідно до встановлених стехіометричних коефіцієнтів компонентів реакції виділено забарвлений продукт взаємодії дилтіазему гідрохлориду з бромкрезоловим зеленим.

Загальна методика виділення продукту реакції: 41,45 мг (0,0001 М) дилтіазему гідрохлориду розчиняли у 5,00 мл ацетону, додавали розчин 69,80 мг $(0,0001$ М) БКЗ у 5,00 мл ацетону, перемішували та залишали на 24 год при кімнатній температурі. Виділений продукт реакції представляє собою цегляночервоні кристали, розчинні в ацетоні, етанолі, метанолі та диметилорормаміді, дуже мало розчинні у воді. Вихід одержаної сполуки складає 91,25 \%.

Ідентифрікація продукту взаємодії дилтіазему гідрохлориду з бромкрезоловим зеленим

3 метою підтвердження утворення йонного асоціату у реакції між дилтіаземом гідрохлоридом та бромкрезоловим зеленим, проведено ІЧ-спектрометричне дослідження дилтіазему гідрохлориду, бромкрезолового зеленого та продукту їх взаємодії (рис. 3).

Вихідні сполуки та йонний асоціат характеризуються наявністю усіх відповідних валентних та деформаційних коливань згідно 3 запропонованими структурами (табл. 1).

В 1Ч-спектрі поглинання БКЗ присутні смуги, що повністю відповідають структурній формулі. Смуги поглинання $-\mathrm{SO}_{2}$ групи (RSO ${ }_{2} \mathrm{OR}$ ) проявляються у вигляді двох піків валентних $v_{\mathrm{s}}$ симетричних $1185 \mathrm{~cm}^{-1}$ (високої інтенсивності) та $v_{\text {as }}$ асиметричних $1381 \mathrm{~cm}^{-1}$ (серед- ньої інтенсивності) коливань. Валентні коливання $v_{\text {он }}$ френольної групи проявляються поглинанням середньої інтенсивності при 3350-3340 см-1, а десрормаційні коливання $\delta_{\text {он }}$ проявляються при $1332 \mathrm{~cm}^{-1}$. Смуги поглинання середньої інтенсивності 1470 та $1370 \mathrm{~cm}^{-1}$ відповідають деформаційним $\delta_{\text {as }}$ асиметричним та $\delta_{\mathrm{s}}$ симетричним коливанням С-H групи $\left(\mathrm{CH}_{3}\right)$ в алканах. Смуга поглинання при 1273 см $^{-1}$ відповідає асиметричним валентним коливанням у тіоетерах, лактонах, зокрема в нашому випадку в угрупуванні C-O-S оксатіолановий цикл в БКЗ. Смуги поглинання в діапазоні 900-700 см-1 відповідають деформаційним коливанням С-Н. Зокрема, поглинання середньої інтенсивнос-

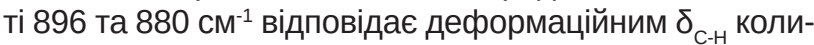
ванням С-H 5-заміщеного бензолу. Смуги поглинання високої інтенсивності при $806 \mathrm{~cm}^{-1}$ відповідають деформаційним коливанням С-H похідних бензолу а при $754 \mathrm{~cm}^{-1}$ відповідають деформаційним коливанням $\mathrm{C}-\mathrm{H}$ в алканах $\left(\mathrm{CH}_{3}\right)$. Поглинання при $637 \mathrm{~cm}^{-1}$ відповідає коливанням C-Br в арилбромідах.

В ІЧ-спектрі дилтіазему наявні смуги поглинання висо-

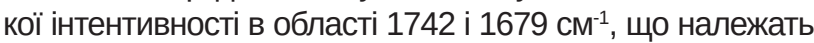
валентним коливанням C=O, в діапазоні 1500-1350 см-1 - десрормаційні коливання С-Н, високоінтенсивні смуги поглинання в області 1250-1130 см-1 відносяться коливань С-О в етерах та естерах. Валентні коливання солянокислого аміну проявляються при $2370 \mathrm{~cm}^{-1}$.

ІЧ-спектр йонного асоціату відповідає сумі поглинань вихідних сполук із деякими відмінностями, що підтверджують його утворення. У йонному асоціаті в області 3600-3400 см ${ }^{-1}$ смуги френольних -ОН прояв-<smiles>Cc1c(C2(c3cc(Br)c(O)c(Br)c3C)OS(=O)(=O)c3ccccc32)cc(Br)c(O)c1Br</smiles>

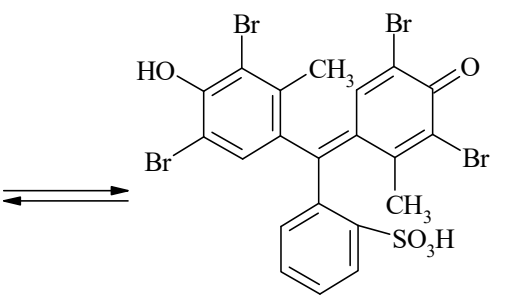<smiles>CC1=C(Br)C(=O)C(Br)=CC1=C(c1ccccc1S(=O)(=O)[O-])c1cc(Br)c(O)c(Br)c1C</smiles>

бромокрезол зелений<smiles>COc1ccc(C2Sc3ccccc3N(CC[NH+](C)C)C(=O)C2OC(C)=[OH+])cc1</smiles><smiles>CC1=C(Br)C(=O)C(Br)=CC1=C(c1ccccc1S(=O)(=O)[O-])c1cc(Br)c(O)c(Br)c1C</smiles>

дилтіазем (протонована форма)

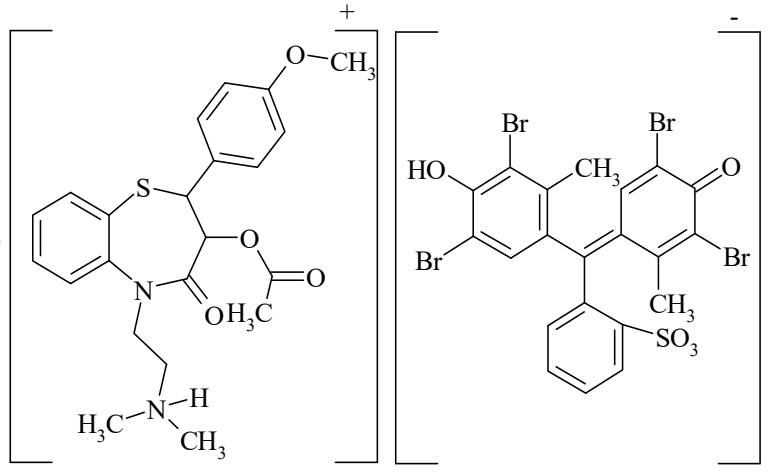

комплекс дилтіазем-бромокрезол зелений

Рис. 3. Схема взаємодії дилтіазему гідрохлориду з бромкрезоловим зеленим.

ISSN 2312-0967. Фармацевтичний часопис. 2018. № 3 
Таблиця 1. Смуги та тип коливань у ІЧ-спектрах досліджуваних сполук, см$^{-1}$

\begin{tabular}{|c|c|c|c|c|c|c|}
\hline \multirow{2}{*}{$\begin{array}{ll} & \text { Група } \\
-\mathrm{OH} & \end{array}$} & \multicolumn{2}{|c|}{ Дилтіазем } & \multicolumn{2}{|c|}{ Бромкрезоловий зелений } & \multicolumn{2}{|c|}{ Продукт } \\
\hline & & & $3350-3340$ & $u$ & - & - \\
\hline$-\mathrm{OH}_{2}^{+}, \mathrm{R}_{3} \mathrm{~N}^{+}$ & & & & & $3200-2000$ & $u$ \\
\hline$-\mathrm{OH}$ & & & 1332 & $\delta$ & - & $\delta$ \\
\hline $\mathrm{C}-\mathrm{H}_{\mathrm{Ar}}$ & & & 3042 & u & \multirow[b]{2}{*}{$3050-2800$} & \multirow[b]{2}{*}{$u$} \\
\hline $\mathrm{C}-\mathrm{H}_{\text {Alk }}$ & & & & $u$ & & \\
\hline $\mathrm{C}-\mathrm{H}_{\mathrm{Ar}}$ & 1510 & $\delta$ & $1530_{\text {сл }}$ & $\delta$ & 1520 & $\delta$ \\
\hline $\mathrm{C}-\mathrm{H}\left(\mathrm{CH}_{3}\right)$ & 1474 & $\delta_{\mathrm{as}}$ & 1470 & $\delta_{\mathrm{as}}$ & 1450 & $\delta_{\mathrm{as}}$ \\
\hline $\mathrm{C}-\mathrm{H}$ & 1412 & & & & & \\
\hline $\mathrm{C}-\mathrm{H}$ & & & 1370 & $\delta_{\mathrm{s}}$ & 1364 & $\delta_{\mathrm{s}}$ \\
\hline С-Н маятникові кол. & & & 1152 & $\delta$ & 1136 & $\delta$ \\
\hline \multirow[t]{2}{*}{ С-H Ar п'ятизаміщені пох. бензолу } & & & 896 & & сл & \\
\hline & & & 880 & & сл & \\
\hline \multirow{2}{*}{ С-H Аr тризаміщені пох. бензолу } & & & & & сл & \\
\hline & 839 & & 806 & & 790 & \\
\hline $\mathrm{C}-\mathrm{H}_{\text {Alk }}$ & 781 & & 754 & & 765 & \\
\hline $\mathrm{R}_{3} \mathrm{~N}^{+} \mathrm{Cl}^{-}$ & 2370 & $u$ & & & - & \\
\hline $\mathrm{R}_{3} \mathrm{~N}$ & 1178 & u & & & 1176 & $\mathrm{u}$ \\
\hline \multirow{2}{*}{$\mathrm{C}=\mathrm{O}$} & 1742 & $u$ & & & $1740_{\text {сл }}$ & $u$ \\
\hline & 1679 & u & & & $1680_{\text {сл }}$ & $u$ \\
\hline $\mathrm{C}=\mathrm{O}$ & & & - & & 1652 сл & \\
\hline \multirow{2}{*}{$\begin{array}{l}\text { O=С-О-С } \\
\text { С-О в етері }\end{array}$} & 1216 & $\mathrm{U}_{\mathrm{as}}$ & & & 1215 & $\mathrm{U}_{\mathrm{as}}$ \\
\hline & 1025 & $u_{s}$ & & & 1016 & $u_{s}$ \\
\hline \multirow{2}{*}{$\mathrm{RSO}_{2} \mathrm{OR}$} & & & 1381 & $\mathrm{u}_{\mathrm{as}}$ & - & \\
\hline & & & 1185 & $u_{s}$ & - & \\
\hline \multirow{2}{*}{$-\mathrm{SO}_{3} \mathrm{H} /-\mathrm{SO}_{3}^{-}$} & & & & & 1240 & $\mathrm{U}_{\mathrm{as}}$ \\
\hline & & & & & 1130 & $u_{s}$ \\
\hline$-\mathrm{C}-\mathrm{O}-\mathrm{S}$ & & & 1273 & $\mathrm{u}_{\mathrm{as}}$ & - & \\
\hline $\mathrm{C}-\mathrm{Br}$ & & & 637 & $u$ & 613 & $u$ \\
\hline
\end{tabular}

Примітки: «-» - поглинання відсутнє, «с» - сильне поглинання, «сл» - слабке поглинання.

ляються з меншою інтенсивністю, що можна пояснити перетворенням БКЗ у хінонну структуру. У продукті також відсутні поглинання в області $2370 \mathrm{~cm}^{-1}\left(\mathrm{R}_{3} \mathrm{~N}^{+} \mathrm{Cl}^{-} \mathrm{y}\right.$ дилтіаземі гідрохлориді), що пояснюється утворенням йонного асоціату з БКЗ, а саме поглинання проявляється у вигляді уширеного сигналу в області 3200$2000 \mathrm{~cm}^{-1}$. Підтвердженням розкриття оксатіоланового циклу в БКЗ є відсутність поглинання угрупуванні C-O-S при $1273 \mathrm{~cm}^{-1}$, що присутнє в спектрі БКЗ. Смуги поглинань сульфогрупи в йонному асоціаті зсунуті і відповідають поглинанню $\mathrm{SO}_{3}{ }^{2-}$. Валентні коливання $\mathrm{C}=\mathrm{O}$ (від дилтіазему гідрохлориду) у йонному асоціаті проявляються з малою інтенсивністю.

Висновки. У результаті проведених досліджень встановлено, що дилтіазему гідрохлорид взаємодіє 3 бромкрезоловим зеленим у співвідношенні 1:1, виділено та встановлено будову продукту взаємодії дилтіазему гідрохлорид з бромкрезоловим зеленим. За допомогою ІЧ-спектроскопії підтверджено, що продуктом реакції є йонний асоціат.

ISSN 2312-0967. Pharmaceutical review. 2018. № 3 
Аналіз лікарських препаратів

\title{
Analysis of drugs \\ ИЗУЧЕНИЕ СТРОЕНИЯ ПРОДУКТА ВЗАИМОДЕЙСТВИЯ ДИЛТИАЗЕМА С БРОМКРЕЗОЛОВЫМ ЗЕЛЕНЫМ
}

\author{
М. И. Сулыма ${ }^{1}$, В. В. Огурцов ${ }^{1}$, Ю. Н. Жук², С. А. Васюк², С. В. Хомяк³ \\ Львовский национальный медицинский университет имени Данила Галицкого ${ }^{1}$ \\ Запорожский государственный медицинский университет ${ }^{2}$ \\ Институт химии и химических технологий Национального университета «Львовская \\ политехника» \\ Sumarta145@gmail.com
}

Цель роботы. Выделение и идентификация продукта взаимодействия дилтиазема гидрохлорида с бромкрезоловым зеленым.

Материалы и методы. В исследовании использованы рабочий стандартный образец дилтиазема гидрохлорида, бромкрезоловый зеленый (БКЗ), образцы готовых лекарственных фрорм отечественного и зарубежного производства. Реагенты и растворители: стандартный образец дилтиазема гидрохлорида, бромкрезоловый зеленый, ацетон.

Аналитическое оборудование: спектрофотометр Bruker Alpha (Bruker Optik GmbH, Ettlingen, Germany) c использованием приставки (полного внутреннего отражения) ATR (прямое введение вещества), спектрофотометр Specord 200 (Германия) (190-1100 нм).

Результаты и обсуждение. Экспериментально установлено, что дилтиаземагидрохлоридвзаимодействует с бромкрезоловым зеленым в среде ацетона с образованием ионного ассоциата. ИК-спектр ионного ассоциата соответствует сумме поглощений исходных соединений с некоторыми отличиями, которые подтверждают его образование. В ионных ассоциатах в области 3600-3400 см-1 полосы фенольных ОН проявляются с меньшей интенсивностью, чем можно объяснить превращением БКЗ в хинонную структуру. В продукте также отсутствуют поглощения в области $2370 \mathrm{~cm}^{-1}\left(\mathrm{R}_{3} \mathrm{~N}^{+} \mathrm{Cl}^{-}\right.$в дилтиаземе гидрохлориде), что объясняется образованием ионного ассоциата с БКЗ, а именно поглощения проявляется в виде уширенного сигнала в области 3200-2000 см-1.

Выводы. В результате проведенных исследований установлено, что дилтиазем гидрохлорид взаимодействует с бромкрезоловым зеленым в соотношении 1:1, выделено и установлено строение продукта взаимодействия дилтиазема гидрохлорида с бромкрезоловым зеленым. С помощью ИК-спектроскопии подтверждено, что продуктом реакции является ионный ассоциат.

Ключевые слова: дилтиазема гидрохлорид; бромкрезоловый зеленый; ионный ассоциат; спектрофотометрия.

\section{STUDY THE STRUCTURE OF DILTIAZEM AND BROMOCRESOL GREEN REACTION PRODUCT}

\author{
M. I. Sulyma ${ }^{1}$, V. V. Ogurtsov ${ }^{1}$, Yu. M. Zhuk ${ }^{2}$, S. O. Vasyuk ${ }^{2}$, S. V. Khomyak ${ }^{3}$ \\ Danylo Halytsky Lviv National Medical University ${ }^{1}$ \\ Zaporizhzhia State Medical University² \\ Institute of Chemistry and Chemical Technologies of Lviv Polytechnic National University ${ }^{3}$ \\ Sumarta145@gmail.com
}

The aim of the work. Selection and identification of the diltiazem hydrochloride and bromocresol green reaction product. Materials and Methods. Diltiazem hydrochloride working standard, bromocresol green and the sample of final dosage forms were used

Reagents and solvents: A standard sample of diltiazem hydrochloride, bromocresol green, acetone.

Analytical equipments: Spectrophotometer Specord Bruker Alpha (Bruker Optik GmbH, Ettlingen, Germany) using a prefix (full internal reflection) ATR (direct injection of substance), Spectrophotometer Specord 200 (Germany) (190$1100 \mathrm{~nm})$

Results and Discussion. It was experimentally established that diltiazem hydrochloride forms coloured ion-pair product with bromocresol green in acetone medium. IR-spectrum ion-pair complex corresponds to the sum of absorption of starting compounds with some differences, which confirm its formation. In ion-pair product in the region $3600-3400 \mathrm{sm}^{-1} \mathrm{strips}^{-3}$ of phenolic $-\mathrm{OH}$ appear with less intensity, which can be explained by the transformation of bromocresol green into the quinone structure. The product also has no absorption in the region $2370 \mathrm{~cm}^{-1}\left(\mathrm{R}_{3} \mathrm{~N}^{+} \mathrm{Cl}\right.$ in diltiazem hydrochloride), which is explained by the formation of the ionic associate with bromocresol green, namely, the absorption is manifested in the form of a wider signal in the region $3200-2000 \mathrm{~cm}^{-1}$.

ISSN 2312-0967. Фармацевтичний часопис. 2018. № 3 
Conclusions. Presented analytical assay showed that diltiazem hydrochloride reacts with bromocresol green in a ratio of 1:1. It was also established and identified the structure of the product of reaction. Using IR-spectroscopy, it was confirmed that is known to be an ionic associate.

Key words: diltiazem hydrochloride; bromocresol green; ionic associate; spectrophotometry.

\section{Список літератури}

1. Eyad S.M. Abu-Nameh. A validated stability indicating HPLC method for determination of diltiazem hydrochloride in tablet dosage form / Eyad S.M. Abu-Nameh // Aust. J. Basic \& Appl. Sci. - 2013. - Vol. 7 (6). - P. P.730-736. 2. Development and validation of a stability indicating HPLC method to determine diltiazem hydrochloride in tablets and compounded capsules / Souza Mateus Araújo Castro e, Pereira Carlos Eduardo de Oliveira, Nogueira Fernando Henrique Andrade, Pianetti Gerson Antônio // Braz. J. Pharm. Sci. - 2017.

3. Development and validation of new assay method for the simultaneous analysis of diltiazem, metformin, pioglitazone and rosiglitazone by RP-HPLC and its applications in pharmaceuticals and human serum / N. Sultana, M. S. Arayne, N. Shafi [et al.] // Journal of Chromatographic Science. - 2011. - Vol. 49 (10). - P.774-779.

4. Validated gradient stability indicating HPLC method for determining Diltiazem Hydrochloride and related substances in bulk drug and novel tablet formulation / A. Vivekanand, N. Chatpalliwara, Pawan Porwala, U. Neeraj // J. Pharm. Anal. - 2012. - Vol. 2 (3). - P. 226-237.

\section{References}

1. Eyad SM, Abu-Nameh A validated stability indicating HPLC method for determination of diltiazem hydrochloride in tablet dosage form. Aust J Basic \& Appl Sci. 2013;7(6): 730-36.

2. Souza Mateus Araújo Castro e, Pereira Carlos Eduardo de Oliveira, Nogueira Fernando Henrique Andrade, Pianetti Gerson Antônio. Development and validation of a stability indicating HPLC method to determine diltiazem hydrochloride in tablets and compounded capsules. Braz J Pharm Sci. [Internet]. 2017.

3. Sultana N, Arayne MS, Shafi N, Siddiqui FA, Hussain A. Development and validation of new assay method for the simultaneous analysis of diltiazem, metformin, pioglitazone and rosiglitazone by RP-HPLC and its applications in pharmaceuticals and human serum. Journal of Chromatographic Science. 2011;49(10): 774-9.

4. Vivekanand A, Chatpalliwara N, Pawan, Porwala, Neeraj U. Validated gradient stability indicating HPLC method for determining Diltiazem Hydrochloride and related substances in bulk drug and novel tablet formulation. J Pharm Anal 2012;2(3): 226-37.
5. Zhao H. Analysis of diltiazem and desacetyl-diltiazem in plasma using modified high-performance liquid chromatography: Improved sensitivity and reproducibility / H. Zhao, M. S. Chow // Pharm. Res. - 2011. - Vol. 6 (5). - P. 428430.

6. Determination of diltiazem based on the reduction of $\mathrm{Cu}(\mathrm{II})-$ BCA complexes in micellar medium / Larissa Zuppardo, Lacerda Sabino, Daniele Cestari Marino, Horacio Dorigan Moya // Canadian Journal of Chemistry. - 2010. - Vol. 88, No. 6. P. 533-539. https://doi.org/10.1139/V10-036.

7. Rajashree Patil Development and validation of zero order deivative by uv- spectrophotometric method for determination of diltiazem hcl in bulk and its formulation / Rajashree Patil, Vijaya Patil, Suryakant Bhosale // International Journal of Universal Pharmacy and Bio Sciences. - 2014. Vol. 3 (4). - P. 1-15.

8. Розробка та валідація методики спектрофротометричного кількісного визначення дилтіазему в лікарських фрормах / М. І. Сулима, В. В. Огурцов, Ю. М. Жук, С. О. Васюк // Фармацевтичний часопис. № 4. - 2017. - C. 57-63.

5. Zhao H, Chow MS. Analysis of diltiazem and desacetyldiltiazem in plasma using modified high-performance liquid chromatography: Improved sensitivity and reproducibility. Pharm Res 2011;6(5): 428-30.

6. Larissa Zuppardo, Lacerda Sabino, Daniele Cestari Marino, Horacio Dorigan Moya. 6. Determination of diltiazem based on the reduction of $\mathrm{Cu}$ (II)-BCA complexes in micellar medium. Canadian Journal of Chemistry, 2010;88 (6):533-9. https://doi.org/10.1139/V10-036 .

7. Rajashree Patil, Vijaya Patil, Suryakant Bhosale. Development and validation of zero order deivative by uv-spectrophotometric method for determination of diltiazem hcl in bulk and its formulation. International Journal of Universal Pharmacy and Bio Sciences, 3(4): July-August. 2014. International Standard Serial Number (ISSN): 2319-8141. 2014;1-15.

8. Sulyma MI, Ohurtsov VV, Zhuk YuM, Vasiuk SO. [Method development and validation of diltiazem in pharmaceutical forms by spectrophotometric quantitative determination]. Farmats chasopys. 2017;4: 57-63. Ukrainian. 